\title{
About the Progressive Tax System of Labor Remuneration in Russia
}

\author{
Marat Y. Ibragimov ${ }^{1}$, Rustam M. Ibragimov ${ }^{2}$, Yuliya M. Sinnikova ${ }^{1} \&$ Aidar M. Tufetulov $^{1}$ \\ ${ }^{1}$ Institute of Economics and Finance, Kazan (Volga Region) Federal University, Russia \\ ${ }^{2}$ South Kensington Campus, London Exhibition Road, United Kingdom \\ Correspondence: Aidar M. Tufetulov, Institute of Economics and Finance, Kazan (Volga Region) Federal \\ University, Russia. 4, Butlerov st., Kazan, 420012, Russia. Tel: 7-432-911-369; 7-987-296-02-92. E-mail: \\ ajdar-t@yandex.ru
}

Received: July 20, 2014 Accepted: August 10, 2014 Online Published: November 14, 2014

doi:10.5539/ass.v10n23p28 URL: http://dx.doi.org/10.5539/ass.v10n23p28

\begin{abstract}
This paper presents the results of research aimed at improvement of the taxation of wages in Russia. It analyses the problem of determining the progressive income tax scale as being a more socially equitable than the current flat rate in Russia with $13 \%$ tax rate on income. Proposed tax scale of tax rates exempts the poor citizens from income tax, shifting the tax burden from the poor to the rich. In accordance with the principle of redistribution that leads to a reduction in income inequality in Russia.

The most important source of budget revenues are taxes. In Russia, as in most countries, the tax on personal income (referred to as PIT) is one of the main sources of budget revenues. Its share of the budget is directly dependent on the level of economic development. This is one of the most popular taxes in the world payable on personal incomes. PIT is linked to consumption, and it can either stimulate consumption or reduce it. Therefore, the main challenge of income taxation is to achieve optimal balance between economic efficiency and social justice of the tax. In other words, such tax is required, which would provide the maximum equitable redistribution of income with minimal damage to the interests of taxpayers from taxation. Analysis of tax on personal income shows that it, as well as the whole tax system in the Russian Federation is constantly developing.
\end{abstract}

Keywords: budget revenues, flat scale, income tax, income tax on individuals, a progressive scale, scale of tax rates

\section{Introduction}

Currently, the tax charged on the physical persons or the so-called income tax is one of the major economic "levers" which allows the state to solve various social and economic problems of the society. Similar to Russian Federation, this tax is one of the sources of income which form the state budget of the majority of the foreign countries.

At the same time, in accordance with the world income tax practices, income tax on individuals under Russian conditions does not resolve the tasks of gaining economic efficiency and social justice at a full effect. The flat scale of the income tax of individuals, which currently exists in Russian Federation is, in our opinion, not socially oriented and in accordance with the redistribution principles leads to the growth in inequalities of the income of the citizens.

The rejection to use progressive taxation scale which is widely used throughout the world, in Russian Federation was guided by the decision to get the income of the citizens out of the shadow economy, but in practice it has demonstrated absolutely opposite effect. The modern Russian system of taxation can be described as being unjust and does not resolve the task of the capturing of high and very high incomes of the individuals. Moreover, the implemented flat scale of taxation have led not to the resolution of the problems related to the shadow economy, but have resulted in incomes being concealed at even a greater scale.

PIT is, perhaps, the most easily controlled tax by the tax authorities, it is rather difficult for taxpayers to evade it. The procedure for levying personal income tax is determined by the 23 chapter of the Tax Code and by the guidelines of the Federal Tax Service. Chapter 23 of the Tax Code was introduced by the Federal Law from August 3, 2000 № 118-FZ. PIT has replaced the income tax that was levied for 11 years at progressive rates. 
This tax has a pronounced proportionate nature, which violates the principle of fairness in taxation, but with the introduction of a flat income rate tax revenues have increased. The main purpose of the introduction of personal income tax in Russia was the need to ensure the withdrawal of a significant amount of shadow income.

Despite the recent progress in the withdrawal of salaries out of the shadows, their volume remains significant, undermining the viability of the pension system. It is important to establish the reasons that motivate and possibly will continue to encourage employers to pay shadow wages and mechanisms used in this framework as well as the consequences of such actions. Previously economic crisis served as the background for such actions. After the adoption of the Federal Law \# 212 "On the insurance premiums to the Pension Fund, Social Insurance Fund, Federal Compulsory Medical Insurance Fund and territorial health insurance funds ", the tax burden on business concerning the salary has seriously increased. Now it is $34 \%$ instead of the previous $26 \%$.

This tax burden is very heavy both for companies and even more for individual entrepreneurs with employees on labor contracts. Businesses cannot operate at a disadvantage, even if the business is socially responsible. This situation contradicts the essence of existence, enshrined in Article 50 of the Civil Code.

But even if in reality not every company is making a loss, the situation in any case is paradoxical: it became unprofitable to hire workers, but at the same time it is impossible to do business without employees at all. Thus, the increase in premiums to $34 \%$ also contributed to the return of payment "in envelopes".

"Shadow", "gray" or hidden wage is a payment to an employee which is not considered for taxation, an informal wage, issued "in envelopes", insurance benefits and annuities received from insurance companies, and a number of other forms. Such schemes are used to evade the payment of insurance contributions for compulsory pension insurance and PIT. Meanwhile, it is obvious that in this way not only the organization actually cheats the state but also worsens the welfare of its employees, because the size of the official salary defines the value of future pension of working citizens, sick leaves pay, including maternity.

The following factors evidence the concealed wages:

- A significant gap between the official and the real income of the population;

- The difference between expenses of certain groups of citizens and their declared incomes;

- Hidden or illegal employment (the large number of economically active population working in enterprises that are not registered with the tax authorities or performing illegal business activities);

- Hidden growth of the money supply used to pay wages.

The existing Russian flat income tax rate is not socially oriented and according to the principle of redistribution leads to increased income inequality. In our paper, we propose to establish the scale of taxation, the most acceptable for the Russian economy in terms of social security, budget revenues and economic growth. One of the main problems with this is the identification of the statistical law of income distribution between households, which is calculated on the basis of fiscal revenues from the income tax.

In accordance with the official statistics, the share of the concealed remuneration for labor in GDP from the year 2001 (from the moment of the acceptance of the of the proportional tax rate on the income tax of individuals) was constantly growing from $11,1 \%$, and currently reached a figure of $15 \%$. Statistical data reveals in Russian Federation, almost each fourth ruble, being paid in the form of salary is being concealed, but actually every third, and for some types of activities, every second ruble is hidden (Medvedeva, 2011).

Consequently, now the formation of the more effective Taxation System for individuals in Russian Federation is becoming more and more urgent, and this system must consider international experience as well. In our opinion, in accordance with the Russian conditions, it is more favorable to use the progressive scale of the taxation rates, as being the most acceptable for the Russian economy form the point of social security, growth of the income coming into the budget and economic growth as a whole.

In order to reform the taxation of individuals in Russian Federation it is deemed reasonable to use the positive experience of the foreign countries, which use the progressive taxation scale quite successfully for decades. The experience of the developed foreign states reflects the existence of some sort of equity of the income in the conditions of the market economy, which is reached by the state on the basis of execution of the applicable social politics based on the significant share of the social expenses from the budget as well as the progressive methods of taxation.

Income tax has the largest average weight in the structure of the budget income of many countries, such as United States of America, Canada, Great Britain, Germany, Japan, France and Denmark. The Share of the Income tax in the GDP of these Countries is quite high and is approximately $8,5-14,0 \%$, which can be 
explained by the high rates of the income tax for the individuals with the highest incomes, which in the number of countries are approximately $50-60 \%$.

It shall also be noted that from 200 countries of the world, the tax system of 15 of them does not use income tax (UAE, Bahamas, Kuwait, Monaco, Qatar, Somali, Uruguay and others), and more than 150 countries use the progressive scale of taxation. As it has been noted, the progressive taxation scale allows to fill in the income of the state budget, as well as levelling out the social differences, which inevitably exists at each country. Most of the countries the progressive scale of the taxation rates has a complex stepped structure, so the income being taxed is split into parts, and each of the parts has its own taxation rate. In some of the countries, the income is split into many parts and consequently, the shift from one group of the tax charged income to the pother is performed gradually. In other countries however, the progression has a very "jumpy" pattern.

In this paper, we propose to review the possibility of implementation of such progressive scale of the tax rates for the income tax on individuals, which will not result in the shrinking of the income of the state budget. In order to perform the calculations, the progressive taxation scale similar to the one used in The United Kingdom of Great Britain was taken. At the same time, the level of income at which the transition to the next taxation rate is performed has been adapted in accordance with the Russian levels of earnings, due to the fact that they are a number of times higher in UK (in comparison to Russian Federation). At the same time, it shall be noted that in UK, similar to the rest of Europe, the rates of income tax of individuals were a lot higher 30-40 years ago, for example in the 70's it was $83 \%$, and the income received from investment was charged at arate of $98 \%$ (Zyskind, 2011).

Income Tax is the main tax which is being withheld in Great Britain. The tax is progressive - it depend on the level of income. The initial amount of income is not charged with any tax and it is the same for all individuals. In the years 2009-2010 this amount was £6475. In the year 2008-09 the rate of $10 \%$ have been cancelled, except the income earned on savings, except the cases, when the rest of the income is less than 2320 pounds per annum. In the years 2009-10 this amount was increased up to $£ 2440$.

Table 1. Scale of the income tax in Great Britain in the year 2009

\begin{tabular}{ccccc}
\hline Tax Rate & $\begin{array}{c}\text { Income earned from } \\
\text { dividends }\end{array}$ & $\begin{array}{c}\text { Income earned from savings } \\
\text { (bank deposits) }\end{array}$ & $\begin{array}{c}\text { Other } \\
\text { income }\end{array}$ & $\begin{array}{c}\text { Level of income } \\
\text { (in GBP) }\end{array}$ \\
\hline Start level & $0 \%$ & $10 \%$ & $0 \%$ & $0-2440$ \\
Base level & $10 \%$ & $20 \%$ & $20 \%$ & $2441-37400$ \\
Maximum Level & $32,5 \%$ & $40 \%$ & $40 \%$ & Higher than 37 400 \\
\hline
\end{tabular}

The second source of financing the state in Great Britain - is the obligatory payments under National Insurance. This tax is paid by the taxpayer and by the employer. There are a number of levels of payments of national insurance for different types of the taxpayers. For persons that are hired by the employer, this level is $11 \%$ from the amount of salary, plus the employer shall pay $12,8 \%$ for each worker hired. The persons employed in their own business, married non-working women and persons who are working in charity organizations are obliged to pay National Insurance as well.

The calculations for Russia, which are described in this paper, are based on the results received from the work of Ibragimov, Ibragimov, Tufetulov (2014). In other words, the statistical law of redistribution of the income between households, we propose as being the combination of the normal and power laws.

\section{Materials and Methods}

In the Article of Ibragimov, Ibragimov, Tufetulov (2014) there are statistical characteristics of the distribution of profits of the households of Russian Federation before the payment of the income tax - Net income. The statistical characteristics of the annual indicators of the random variable (s. v.) Net income, and random variable $Y=4$ Net income are represented in the Table 2. Consequently we propose that the distribution of the annual values of the income in the quarter 4 of 2009.

Table 2. Statistical Characteristics Net income, rubles per quarter and $Y$, rub. Per annum

\begin{tabular}{ccccc}
\hline Indicators & Sample Volume, $n$ & Average Value, $m$ & Standard deviation, $s$ & Maximum, $I_{\max }$ \\
\hline Net income & \multirow{2}{*}{51309} & 72566 & 63076 & 3599033 \\
$Y$ & & 290264 & 252304 & 14396132 \\
\hline
\end{tabular}


In the article of Ibragimov, Ibragimov, Tufetulov (2014) have also valued the major parameters of the function of distribution of the income, which is represented by the combination of the normal and power logarithmic laws:

where $b=445000$,

$$
F(y)=\left\{\begin{array}{c}
\frac{1}{y \sigma \sqrt{2 \pi}} \cdot \int_{0}^{y} e^{-\frac{(\ln y-\mu)^{2}}{2 \sigma^{2}}}, y<b \\
1-\frac{A}{y^{k}}, y \geq b
\end{array}\right.
$$

$$
\begin{aligned}
& A=\exp (27.04)=5.52981 \mathrm{E}+11, \\
& \hat{\mu}=10.94 \\
& \widehat{\sigma}=0.71 \\
& \widehat{\mathrm{K}}=2.552 .
\end{aligned}
$$

Hereinafter we will propose that the variable coefficient $V=\frac{s}{|m|}$ a. v. $Y$ for the distribution in Russia is constant, so it is equal $V=\frac{63076}{72566}=0.87$ and is not changing over time. Consequently, if we do know the value of the average income $m$ a.v. $Y$ in the future, we can evaluate the value of the standard deviation of this average value as $s=0.87 \mathrm{~m}$, and then evaluate the parameters of the function of the normal logarithmic distribution a in (1), by solving the system of equations

$$
\left\{\begin{array}{c}
e^{\mu+\frac{\sigma^{2}}{2}}=m \\
e^{\mu+\frac{\sigma^{2}}{2}} \cdot \sqrt{e^{\sigma^{2}}-1}=s .
\end{array}\right.
$$

Let's propose that the parameter $b$ of the function of distribution of the profits (1) is proportional to the mathematical expectation of the a.v. $Y$, which is $\frac{b_{t+1}}{b_{t}}=\frac{m_{t+1}}{m_{t}}$, where $t$ - is the time period concerned.

The value of the parameter $A$ for the function of distribution (1) can be evaluated by using, the condition of equality of the functions of normal and power logarithmic law of distribution:

By using the condition of equality of the values of the functions of the normal and power logarithmic law of distribution at $y=b$ :

$$
\frac{1}{b \sigma \sqrt{2 \pi}} \cdot \int_{0}^{y} e^{-\frac{(\ln b-\mu)^{2}}{2 \sigma^{2}}}=1-\frac{A}{b^{k}} .
$$

The proposals made above, give us the possibility on the basis of the forecasted values, to forecast the parameters of the function of distribution (1) and calculate the volumes of the income into budget at various scales of the rate of the income tax.

\section{Results}

In Great Britain, the average corrected net effected income of the households, after payment of the taxes is 26904 US Dollars per annum. In the year 2007 the average annual income of the households in UK was 36.4 thousand UK pounds and 33.2 thousand UK pounds in the year 2011.

In accordance with the Table 2, the average income in Russia, in the $4^{\text {th }}$ quarter of 2009 was 72566 rubles per annum which equals to 290 thousand rubles per annum. The exchange rate of the UK pound in the quarter 4 of 2009 was at an average of 48.16 rubles per pound. Consequently, the evaluation of the annual income of the households in Russia in the $4^{\text {th }}$ quarter of is equal to 6022 UK pounds, which is approximately 6 times less, than in UK. Consequently the scale of the income tax which is analogue to British will look as presented in the table 3.

Table 3. Scale of the income tax for Russia, similar to British

\begin{tabular}{ccc}
\hline Tax Rate Level & Annual income, rub & Level of Income in Rubles \\
\hline Starting Level & $0 \%$ & $0-20000$ \\
Base Level & $20 \%$ & $20001-300000$ \\
Maximum Level & $40 \%$ & above 300 thousand. \\
\hline
\end{tabular}


We shall also review the alternative scale (ref to Table 4).

Table 4. Alternative scale for the income tax for Russia

\begin{tabular}{ccc}
\hline Tax Rate Level & Annual income, rub & Level of Income in Rubles \\
\hline Starting Level & $0 \%$ & $0-20000$ \\
Level 1 & $13 \%$ & $20001-300000$ \\
Level 2 & $20 \%$ & $300001-1$ million. \\
Maximum Level & $40 \%$ & above 1 million.. \\
\hline
\end{tabular}

Budget in payments $T A X$ were calculated in accordance with the formula

$$
T A X=n \int_{0}^{I_{\max }} r_{y} y f(y) d y,
$$

where $f(y)$ - is the function of density of the distribution of probabilities (pdf) of the distribution of the income in Russia:

$$
f(y)=F^{\prime}(y)=\left\{\begin{array}{c}
\frac{1}{y \sigma \sqrt{2 \pi}} \cdot e^{-\frac{(\ln y-\mu)^{2}}{2 \sigma^{2}}}, y<b ; \\
\frac{k A}{y^{k+1}}, y \geq b,
\end{array}\right.
$$

$I_{\max }$ - maximum (officially reported) level of income. Consequently,

$$
T A X=n \int_{0}^{b} r_{y} y f(y) d y=\frac{n}{\sigma \sqrt{2 \pi}} \int_{0}^{b} r_{y} e^{-\frac{(\ln y-\mu)^{2}}{2 \sigma^{2}}} d y+\left.n r_{y} \frac{k(1-k) A}{y^{k-1}}\right|_{b} ^{I_{m a x}}
$$

where $r_{y}$ - is the tax rate for the level of income $y, n=51309$ - sample volume (ref to. Table 2), $b=1780000$, $k=2.552, m=290264, s=0.87 m=63132.42$, a $\mu$ and $\sigma$ were found as the solution of the system of equations

$$
\left\{\begin{array}{c}
e^{\mu+\frac{\sigma^{2}}{2}}=m ; \\
e^{\mu+\frac{\sigma^{2}}{2}} \cdot \sqrt{e^{\sigma^{2}}-1}=s,
\end{array}\right.
$$

which is

$$
\left\{\begin{array}{c}
\sigma=\sqrt{\ln \left(1+\frac{s^{2}}{m^{2}}\right)} \\
\mu=\ln \frac{m^{3}}{m^{2}+s^{2}}
\end{array}\right.
$$

From $\mu=12.015, \sigma=0.751$. The value $A$ can be found from the condition $\frac{1}{y \sigma \sqrt{2 \pi}} \cdot e^{-\frac{(\ln y-\mu)^{2}}{2 \sigma^{2}}}=\frac{k A}{y^{k+1}}$ at $y=b$. While,

$$
A=\frac{b^{k}}{k \sigma \sqrt{2 \pi}} \cdot e^{-\frac{(\ln b-\mu)^{2}}{2 \sigma^{2}}}
$$

so $A=12.332 \mathrm{E}+12$.

We hereby have:

$$
T_{1}=\left.n r_{y} \frac{k(1-k) A}{y^{k-1}}\right|_{b} ^{I_{\max }}=\left.51309 \cdot 0.4 \frac{k(1-k) A}{y^{k-1}}\right|_{b} ^{I_{\max }}=192 \text { million rubles }
$$

The appropriate results of the calculations are provided in the Table 6 (here-Option 1 is in accordance with the flat scale of the Income tax in Russia at 13\%, option 2 to the scale represented in Table 3, Option 3 to the scale represented in Table 4). But for the option 2 the integral was found

$$
T_{2}=\frac{n}{\sigma \sqrt{2 \pi}} \int_{0}^{b} r_{y} e^{-\frac{(\ln y-\mu)^{2}}{2 \sigma^{2}}} d y=\frac{n}{\sigma \sqrt{2 \pi}}\left[0.2 \int_{b_{1}}^{b_{2}} e^{-\frac{(\ln y-\mu)^{2}}{2 \sigma^{2}}} d y+0.4 \int_{b_{2}}^{b} e^{-\frac{(\ln y-\mu)^{2}}{2 \sigma^{2}}} d y\right],
$$

where $b_{1}=20000, b_{2}=300000, b=1780000$. For the Option 3 the integral was calculated 


$$
T_{2}=\frac{n}{\sigma \sqrt{2 \pi}}\left[0.13 \int_{b_{1}}^{b_{2}} e^{-\frac{(\ln y-\mu)^{2}}{2 \sigma^{2}}} d y+0.2 \int_{b_{2}}^{b_{3}} e^{-\frac{(\ln y-\mu)^{2}}{2 \sigma^{2}}} d y+0.4 \int_{b_{3}}^{b} e^{-\frac{(\ln y-\mu)^{2}}{2 \sigma^{2}}} d y\right]
$$

where $b_{3}=1$ million rubles. The values of the integrals $\int_{b_{i}}^{b_{j}} e^{-\frac{(\ln y-\mu)^{2}}{2 \sigma^{2}}} d y$, were calculated with the Wolfram Mathematica 9 system and are provided in Table 5.

So, at the use of progressive scale of the rates of the income tax, similar to the British (option 2), the expected budget earnings are 1,8 times higher than at the flat scale of 13\% (Option 1). The expected budget earnings for the option 3 are approximately equal to the budget earnings under option 1. However options 2 and 3 are more socially just than the option 1 .

Table 5. Values of the Integrals $\int_{b_{i}}^{b_{j}} e^{-\frac{(\ln y-\mu)^{2}}{2 \sigma^{2}}} d y$

\begin{tabular}{lr}
\hline$b_{i}=20000, b_{j}=300000$ & 213181 \\
\hline$b_{i}=300000, b_{j}=b$ & 195559 \\
\hline$b_{i}=300000, b_{j}=1000000$ & 178318 \\
\hline$b_{i}=1000000, b_{j}=b$ & 17241.2 \\
\hline
\end{tabular}

Table 6. Level of expected budget earnings at various options of the income tax scale, $T A X=T_{1}+T_{2}$

\begin{tabular}{lcc}
\hline Scale of the Income Tax & $\begin{array}{c}\text { Budget inpayments, } T A X, \\
\text { rub per annum }\end{array}$ & Average rate of the income tax, $r$ \\
\hline Option 1 & $1,936,110,225$ & 0.13 \\
Option 2 & $3,487,731,204$ & 0.234 \\
Option 3 & $2,108,268,433$ & 0.14 \\
\hline
\end{tabular}

Note. The budget income are calculated on the sample of the households selected in the $4^{\text {th }}$ quarter 2009 (sample volume $n=51309$ ) and can be used only for comparison of the various options of the scale of the income tax. The average rate of the income tax $=\frac{T A X}{A I}$, where $A I-$ is the total income of the households in the selection of the annual incomes $Y$.

\section{Conclusion}

On the basis of the study performed by us, we can hereby conclude that the main problem of the taxation of the income of the individuals in Russian Federation is related to the continuous use of the flat scale of the tax rate.

Review of the foreign experience of the taxation of individuals allows us to conclude that almost all foreign countries use the progressive tax rate, and the problem of significant inequality of the society in accordance with their level of income existing in Russian Federation, have been resolved by foreign countries long time ago. All developed and highly developed countries of the world use the upper rate of the income tax from 30 to $60 \%$ of the total income, and the progression varies from 2-step to 18-step scale of the tax.

As it has been noted before, with the use of the progressive scale of the rates of the income tax similar to the British (Option 2), the expected budget in payments are 1.8 times greater than when utilizing the flat scale of $13 \%$. The expected budget inpayments that we proposed for the Option 3 are almost equal to the inpayments into the budget under Option 1. However options 2 and 3 are socially more just than the option 1 . However, the most preferable option is option 3. This is related to the fact that the GDP growth is larger if there are less taxes and payments coming from the workers and the employers.

Concluding on all of the above, it shall be noted that for Russian Federation it will be reasonable to implement the progressive scale of taxation of the individuals and set such rates, which will allow to duly increase the tax burden onto the large income.

The implementation of the progressive scale of the Income tax will stimulate the economic growth of Russian federation, realization of the major directions of tax and budget policies and transfer of the country to the path of the countries which are successful in their market economy. 


\section{References}

Aliev, B. H., Kagirgadzhieva, Z. K., \& Kadieva, A. (2011). Potential use of the personal income tax in Russia and in the industrialized countries. Taxes and Taxation, 311(463), 9.

Atkinson, A. B., Piketty, T., \& Saez, E. (2009). Top Incomes in the Long Run of History. NBER Working Paper, № 15408, Cambridge, MA.

Autor, D. H., Katz, L. F., \& Kearney, M. S. (2008). Trends in U.S. wage inequality: Revising the revisionists. Review of Economics and Statistics, 90(2), 300-323. http://dx.doi.org/10.1162/rest.90.2.300

Barbaro, S., \& Suedekum, J. (2009). Voting on income tax exemptions. Public Choice, 138(1-2), 239-253. http://dx.doi.org/10.1007/s11127-008-9354-2

Dinardo, J., Fortin, N. M., \& Lemieux, T. (1996). Labor market institutions and the distribution of wages, 1973-1992: A semiparametric approach. Econometrica, 64(5), 1001-1044. http://dx.doi.org/10.2307/ 2171954

Goolsbee, A. (1999). Evidence on the high-income Laffer curve from six decades of tax reform. Brookings Papers on Economic Activity, (2), 1-64. http://dx.doi.org/10.2307/2534678

Gruber, J., \& Saez, E. (2002). The elasticity of taxable income: Evidence and implications. Journal of Public Economics, 84(1), 1-32. http://dx.doi.org/10.1016/S0047-2727(01)00085-8

Ibragimov, M. Y., Ibragimov, R. M., \& Tufetulov, A. M. (2014). The setting of the tasks of the optimization of the scale of the income tax in Russian Federation. Kazan Economy Bulletin.

Jones, L. E., Manuelli, R. E., \& Rossi, P. E. (1997). On the optimal taxation of capital income. Journal of Economic Theory, 73(1), 93-117. http://dx.doi.org/10.1006/jeth.1996.2238

Judd, K. L. (1999). Optimal taxation and spending in general competitive growth models. Journal of Public Economics, 71(1), 1-26. http://dx.doi.org/10.1016/S0047-2727(98)00054-1

Juhn, C. (1999). Wage inequality and demand for skill: Evidence from five decades. Industrial and Labor Relations Review, 52(3), 424-443. http://dx.doi.org/10.2307/2525143

Kopczuk, W. (2005). Tax bases, tax rates and the elasticity of reported income. Journal of Public Economics, 89, (11-12), 2093-2119. http://dx.doi.org/10.1016/j.jpubeco.2004.12.005

Kuznets S. (1953). Shares of Upper Income Groups in Income and Savings. New York: National Bureau of Economic Research.

Medvedeva, O. V. (2011). Results of the implementation of the flat taxation scale for the income of the individuals. Financial problems of the revival of the economy of the State and enterprises in market conditions M.: Institute of Economy and ant crisis management.

OECD Better Life Index. United Kingdom. Retrieved from http://www.oecdbetterlifeindex.org/ru/countries/ united-kingdom-ru/

Saez, E. (2001). Using elasticities to derive optimal income tax rates. Review of Economic Studies, 68(1), 205-229. http://dx.doi.org/10.1111/1467-937X.00166

Saez, E. (2004). Tax Policy and the Economy (Ed., J. Poterba). Cambridge, MA: The MIT Press.

Saez, E., Slemrod, J. B., \& Giertz, S. H. (2009). The Elasticity of Taxable Income with Respect to Marginal Tax Rates: A Critical Review. NBER Working Paper, No. 15012.

Slemrod, J., \& Kopczuk, W. (2002). The optimal elasticity of taxable income. Journal of Public Economics, 84(1), 91-112. http://dx.doi.org/10.1016/S0047-2727(01)00095-0

Stiglitz, J. E. (1982). Self-selection and Pareto efficient taxation. Journal of Public Economics, 17(2), 213-240. http://dx.doi.org/10.1016/0047-2727(82)90020-2

Taxation in the United Kingdom. From Wikipedia, the free encyclopedia.

Time o clock "Rate of English pound sterling". Retrieved from http://time-clock.biz/kursy/gbp

Vesti "Economics "Income of households in Britain fell to $9 \%$ in 5 years". Retrieved from http://www.vestifinance.ru/articles/24947

Wagstaff, A., \& Van Doorslaer, E. (2001). What makes the personal income tax progressive? A comparative analysis for fifteen OECD countries. International Tax and Public Finance, 8(3), 299-315. 
http://dx.doi.org/10.1023/A:1011268209860

Zyskind, I. (2011). The notes of the English lawyer. Note 12. The taxes of the individuals in UK - have paid the taxes and sleep calm. Retrieved from http://igor-zyskind.livejournal.com/3685.html

\section{Copyrights}

Copyright for this article is retained by the author(s), with first publication rights granted to the journal.

This is an open-access article distributed under the terms and conditions of the Creative Commons Attribution license (http://creativecommons.org/licenses/by/3.0/). 